\title{
PD-L1 Positive
}

National Cancer Institute

\section{Source}

National Cancer Institute. PD-L1 Positive. NCI Thesaurus. Code C128554.

An immunohistochemical test result that indicates expression of PD-L1 in a tissue sample of a primary or metastatic malignant neoplasm. 